\title{
Effects of severe undernutrition on body weight and fat tissue changes in dry Lacaune ewes
}

\author{
F Bocquier, Y Chilliard
}

\begin{abstract}
INRA, Laboratoire "Sous-Nutrition des Ruminants", Theix, 63122 Saint-Genès-Champanelle, France
\end{abstract}

The aim of this experiment was to examine the effects of both severity and duration of undernutrition on body weight changes and fat tissue variations in dry Lacaune ewes. Twenty-three mature (6-7 years old) ewes were divided in 4 groups of similar initial bodyweight (BW $=66-68$ $\mathrm{kg}$ ); group $A$ : control, slaughtered initially; groups $B$ and $C$ : ewes fed at $60 \%$ of maintenance energy requirements $(60 \% \mathrm{M})$ for 85 and $81 \mathrm{~d}$, respectively, B ewes were slaughtered and $C$ ewes were fed at $36 \% \mathrm{M}$ for 36 more days (total of $117 \mathrm{~d}$ for group C); group D: ewes fed directly $34 \% M$ for 64 d. The diet consisted of straw, hay and minerals. Energy intake was adjusted weekly to the theoretical maintenance energy requirements $(M=$ 374 kJ ME/kg BW0.75; ME: metabolizable energy). At slaughter, gut content was removed, omental adipose tissue was weighed, and backfat thickness was measured.

Ewes in the $B$ and $C$ groups were submitted to $60 \% \mathrm{M}$ supply and lost about $9 \mathrm{~kg} \mathrm{BW}$ in 85 or 81 d. Ewes in the $C$ group subsequently lost 12.0 $\mathrm{kg}$ more when fed at $36 \% \mathrm{M}$ during the remaining $36 \mathrm{~d}$. $\mathrm{D}$ ewes directly submitted to severe undernutrition (34\% M) lost $21.1 \mathrm{~kg}$ BW in $64 \mathrm{~d}$ (table I). The total BW losses were similar in groups $\mathrm{C}$ and
$D$, although the theoretical energy balances ( $T$ EB) were different: -407 and $-328 \mathrm{MJ}$ ME (table I). Up to $-328 \mathrm{MJ}$, the $\mathrm{C}$ ewes had lost $13.6 \mathrm{~kg}$. The duration and intensity of undernutrition did not significantly affect final empty BW, omental fat weight and backfat thickness in $C$ and $D$ ewes (table I).

The ratio of BW loss $(\mathrm{kg})$ to a $100 \mathrm{ML}-\mathrm{ME}$ theoretical energy deficit for each period (table I) and sub-period was computed. It was the lowest (3.6) for ewes with moderate underfeeding (group B). With accentuated underfeeding (group C), this ratio was 5.1 , while with severe underfeeding (group D) it was higher (6.4). At the beginning of each severe (around $35 \% \mathrm{M}$ ) undernutrition subperiod the ratio was always very high: 7.8 for the $\mathrm{D}$ group (in $12 \mathrm{~d}$ ) and 7.6 for the $\mathrm{C}$ group (in $36 \mathrm{~d}$ ). This shows that with moderate undernutrition ewes can adapt in order to avoid high BW losses. But with severe undernutrition (around 35\% M) they first lose BW rapidly $(7.7 \mathrm{~kg} / 100 \mathrm{MJ}$ energy deficit), and then reduce this ratio to $5.0 \mathrm{~kg} / 100 \mathrm{MJ}$ during the last $20 \mathrm{~d}$, probably as a physiological limit. However, further studies on gut content and body composition are needed to better understand these adaptations.

Table I. In vivo and post mortem measurements in underfed ewes (mean, (SD)).

$\begin{array}{cccccccc}\text { Groups (duration) } & n & \begin{array}{c}\text { Initial BW } \\ (\mathrm{kg})\end{array} & \begin{array}{c}B W \text { changes } \\ (\mathrm{kg})\end{array} & \begin{array}{c}E \text { balance } \\ \left(M J M E^{*}\right)\end{array} & \begin{array}{c}\text { Final EBW } \\ \left(\mathrm{kg}^{* *}\right)\end{array} & \begin{array}{c}\text { Omental fat } \\ (\mathrm{kg})\end{array} & \begin{array}{c}\text { Backfat } \\ (\mathrm{mm})\end{array}\end{array}$

\begin{tabular}{|c|c|c|c|c|c|c|c|}
\hline A: control & 6 & $67.8(8.4)$ & - & - & $53.7(10.5)$ & $2.35(0.9)$ & $10.1(4.6)$ \\
\hline$\% M(85 d)$ & 6 & $67.5(5.8)$ & $-9.4(2.8)$ & $-257(33)$ & $46.5 \quad(4.9)$ & $1.14(0.5)$ & $4.2(2.8)$ \\
\hline C: $56 \% M(117 d)$ & 5 & $66.7(5.8)$ & $-20.7(2.3)$ & $-407(46)$ & (3.3). & $0.70(0.4)$ & $0.5(1.1)$ \\
\hline$\% M(64 d)$ & 6 & $66.5(8.0)$ & $-21.1(3.3)$ & $-328(47)$ & (6.9) & $0.82(0.7)$ & $0.0(0.0)$ \\
\hline
\end{tabular}

" Theoretical energy balance; ** empty body weight. 